DOI

\title{
ВПЛИВ ДЕЯКИХ ФАКТОРІВ НА РИЗИК РОЗВИТКУ АНЕМІЇ ПІД ЧАС ВАГІТНОСТІ
}

\author{
๑А. С. Долгіх, Я. О. Михалко, І. І. Кутчак \\ ДВНЗ «Ужгородський національний університет»
}

\begin{abstract}
РЕЗЮМЕ. У роботі наведено результати дослідження частоти анемій у вагітних під час різних триместрів та вплив на зниження рівня гемоглобіну віку жінки, характеру ії̈ менструальної функції, а також історії вагітностей та пологів. Частота анемії під час вагітності у 2015 році склала 57,34 \%, що є серйозною проблемою для суспільної охорони здоров'я та потребує негайних профілактичних заходів. Підтверджено позитивний вплив куріння на концентрацію гемоглобіну, а викидні та загрози переривання вагітності в анамнезі, так само як і тривалі менструації, не $\epsilon$ факторами ризику розвитку анемії під час вагітності для всіх вікових груп жіночого населення.

КЛЮчОВІ СЛОВА: анемія, вагітність, фактори ризику, вік, куріння, викидні, загроза переривання вагітності.
\end{abstract}

Вступ. За даними Всесвітньої організації охорони здоров'я (ВООЗ), на анемію в світі страждають близько двох мільярдів осіб [1]. Поширеність значень гемоглобіну $(\mathrm{Hb})$ нижче його специфічного рівня для населення була використана для класифікації країн за рівнем даної проблеми для суспільної охорони здоров'я [2].

Проте точна інформація про поширеність анемій у вагітних на різних триместрах відсутня. Особливо це важливо для третього триместру, коли розвиток анемії, ймовірно, найбільше впливає на ризик материнської смертності [2].

В Україні скринінг на анемію у вагітних жінок проводиться при першому візиті пацієнтки до жіночої консультації та у терміні 29 тижнів [3]. При цьому анемію діагностують якщо рівень Нь нижче 110 г/л, незалежно від триместру [4]. В той же час, відповідно до критеріїв Центру з контролю і профілактики захворювань США і ВООЗ, анемія під час вагітності діагностується при концентрації Нb нижче 110 г/л протягом першого або третього триместру та нижче 105 г/л під час другого триместру [5].

Виділяють багато факторів ризику розвитку анемії під час вагітності: недостатнє споживання багатих на залізо продуктів, надмірна кількість інгібіторів всмоктування заліза в раціоні, знижені запаси заліза з дитинства, втрата заліза під час менструацій, підліткова вагітність тощо [6]. Варто зазначити, що в осіб молодше 23 років немає достатнього запасу заліза в організмі, оскільки пул заліза формується до 24 років [7]. Також помічено, що жінки, які використовують засоби внутрішньоматкової контрацепції, мають підвищений ризик розвитку дефіциту заліза [8], тоді як куріння призводить до зростання концентрації $\mathrm{Hb}$ [9].

Мета дослідження. Визначення частоти анемій у жінок у різних триместрах вагітності та вплив віку жінки, характеру її менструальної функції, історії вагітностей та пологів на зниження рівня гемоглобіну.
Матеріал і методи дослідження. Ретроспективно було проаналізовано 307 карток вагітних, які перебували на обліку у Хустській районній поліклініці протягом 2014-2015 років. Середній вік цих жінок становив $(26,00 \pm 5,66)$ років. Визначали кореляційні зв'язки між рівнями Нb під час різних триместрів вагітності та віком жінки, курінням, кількістю вагітностей, абортів та викиднів в анамнезі, наявністю загроз переривання останньої вагітності, тривалістю менструацій, віком початку менархе та статевого життя. Статистичний аналіз даних проводили за допомогою пакета прикладних програм Statistica 8.0 (StatSoft, США).

Результати й обговорення. У 2014 році під час вагітності анемія була виявлена у 62 вагітних (37,8 \%), тоді як у 2015 році анемія під час вагітності траплялася дещо частіше і була зафіксована у 82 жінок (57,35 \%), причому вказана різниця була статистично вірогідна $(p<0,05)$.

Було обраховано частоту виявлення анемій (рівень Нb менше 110 г/л під час всіх триместрів) вперше під час різних триместрів вагітності (рис. 1).

Вивчення частоти вперше виявленої анемії показало, що у 10 жінок (16,13\%) у 2014 році та у 7 жінок (8,54 \%) у 2015 році під час другого триместру рівень Нь був у межах від 105 до 110 г/л, а в інших триместрах був вищий, ніж 110 г/л. Тобто, згідно з українським клінічним протоколом, ці жінки страждали на анемію, а відповідно до рекомендацій ВООЗ їх можна вважати здоровими.

у більшості вагітних було виявлено анемію легкого ступеня (Нb 109-90 г/л). Анемія середньої тяжкості (Hb 89-70 г/л) мала місце у 3 жінок у 2014 році та у 7 жінок у 2015 році (4,84 \% та 8,54 \% відповідно).

Вивчення кореляційних зв'язків між досліджуваними показниками показало наявність слабкого прямого кореляційного зв'язку між рівнем Нb у другому триместрі і віком вагітної $(R=0,146 ; p=0,017)$, тобто, чим молодша була вагіт- 


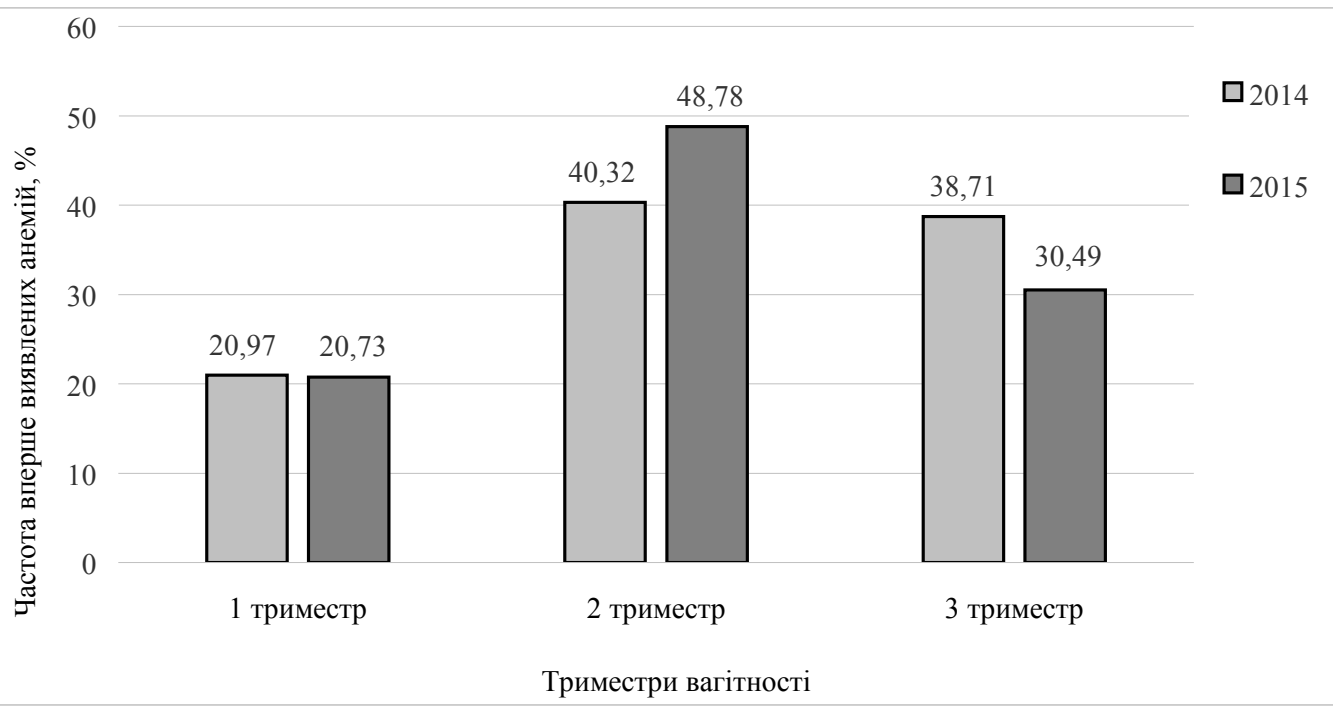

Рис. 1. Частота вперше виявленої анемії під час різних триместрів вагітності у 2014-2015 роках.

Примітка: * - різниця статистично вірогідна при порівнянні показників вперше виявлених анемій під час різних триместрів у 2014 i 2015 роках, $\mathrm{p}<0,05$.

на, тим нижчими були показники Нb. Також виявлено прямий кореляційний зв'язок між віком жінки на момент вагітності та віком початку менархе і початку статевого життя ( $R=0,231$ та $\mathrm{R}=0,400$ відповідно, для всіх $\mathrm{p}<0,001)$.

Серед вагітних, які перебували на обліку у 2014 році, курили 16 жінок (9,76\%), у 2015 році 14 (9,79\%). При цьому серед вагітних з анемією курці траплялися дещо рідше (2,94 \% проти 6,86 \%, $\mathrm{p}=0,056)$, що підтверджує дані літератури про позитивний вплив куріння на концентрацію Нb крові.

Протягом 2014-2015 років 63 вагітні жінки мали в анамнезі викидні. Привертає увагу, що частота викиднів серед вагітних з анемією була вірогідно нижчою, порівняно з жінками без анемії (7,19 \% проти 13,40 \% відповідно, p=0,047). Тому викидні не $\epsilon$ фактором ризику розвитку анемії під час наступної вагітності.

У вагітних віком 25-30 років загрози переривання вагітності траплялися вірогідно частіше при наявності анемії $(11,93 \%$ у жінок з анемією проти

\section{ЛІТЕРАТУРА}

1. Assessing the iron status of populations: including literature reviews: report of a Joint World Health Organization / Centers for Disease Control and Prevention Technical Consultation on the Assessment of Iron Status at the Population Level. - Second edition. - Geneva: Switzerland, 2007. - 108 p.

2. Worldwide prevalence of anaemia 1993-2005: WHO global database on anaemia / Edited by B. de Benoist, E. McLean, I. Egli and M. Cogswell. - Geneva: World Health Organisation, 2008. - $41 \mathrm{p}$.

3. Наказ МОЗ України № 417 від 15.07.2011 «Методичні рекомендації щодо організації надання амбула-
3,67 \% у жінок без анемії, $\mathrm{p}=0,003)$, а куріння вірогідно частіше траплялося серед жінок без анемії під час вагітності, порівняно з жінками з анемією $(9,17 \%$ проти $0,92 \%, p=0,023)$.

У анемічних жінок віком 36 років і старше тривалість менструацій була вірогідно більшою, ніж у жінок без анемії під час вагітності $((5,70 \pm 1,06)$ проти $(4,22 \pm 0,83), p=0,004)$.

\section{Висновки.}

1. Частота анемії під час вагітності у 2015 році склала $57,34 \%$, що $є$ серйозною проблемою для суспільної охорони здоров'я і потребує негайних профілактичних заходів.

2. Підтверджено позитивний вплив куріння на концентрацію гемоглобіну, а викидні, загрози переривання вагітності та тривалі менструації не $\epsilon$ факторами ризику розвитку анемії під час вагітності для всіх вікових груп жіночого населення.

Перспективи подальших досліджень. Оцінити вплив характеру харчування жінки на розвиток анемії під час вагітності.

торної акушерсько-гінекологічної допомоги». - [Електронний ресурс]. - 162 с. - Режим доступу : http://www. moz.gov.ua/ua/portal/dn_20140109_0007.html

4. Наказ МОЗ України № 782 від 29.12.2005 «Про затвердження клінічних протоколів з акушерської та гінекологічної допомоги». - [Електронний ресурс]. - Режим достуny: http://www.moz.gov.ua/ua/portal/dn_20131128_0.html

5. Peña-Rosas J. P. Effects and safety of preventive oral iron or iron+folic acid supplementation for women during pregnancy (Review) / J. P. Peña-Rosas, F. E. Viteri / The Cochrane Collaboration. Published by John Wiley \& Sons. 2009. $-239 \mathrm{p}$. 
Огляди літератури, оригінальні дослідження, погляд на проблему

6. WHO/UNICEF/UNU. Iron deficiency anaemia: assessment, prevention and control, a guide for programme managers. - Geneva: World Health Organization, 2001. $114 \mathrm{p}$.

7. WHO. Guideline: Daily iron and folic acid supplementation in pregnant women. - Geneva: World Health Organization, 2012. - 27 p.
8. Sharman A. Anemia testing in population-based surveys: General information and guidelines for country monitors and program managers / A. Sharman. - Calverton, Maryland USA: ORC Macro, 2000. - 83 p.

9. WHO. Haemoglobin concentrations for the diagnosis of anaemia and assessment of severity / Vitamin and Mineral Nutrition Information System. - Geneva: World Health Organization, 2011. -6 p.

\title{
THE INFLUENCE OF CERTAIN FACTORS ON THE RISK OF ANEMIA DURING PREGNANCY
}

@A. S. Dolhikh, Ya. O. Mykhalko, I. I. Kutchak

\author{
Uzhhorod National University
}

SUMMARY. The aim of the study was to determine the frequency of anemia during different trimesters of pregnancy and the effects of women's age, the nature of menstrual function and history of pregnancy and childbirth on the hemoglobin levels. The frequency of anemia during pregnancy in 2015 was $57.34 \%$, so it is a serious problem for public health and requires the immediate preventive measures in compared with the rate in 2014. The positive impact of smoking on the concentration of hemoglobin was confirmed; miscarriage and threatened abortion history, as well as prolonged menstruation are not the risk factors for anemia in pregnancy for all age groups of the female population.

KEY WORDS: anemia, pregnancy, risk factors, age, smoking, miscarriage, threatened miscarriage.

Отримано 13.04.2016 